\title{
Comparative growth of the intertidal barnacle Tetraclita stalactifera (Thoracica: Tetraclitidae) in sites influenced by upwelling and tropical conditions at the Cabo Frio region, Brazil
}

\author{
Luís Felipe Skinner ${ }^{1}$, Fernanda Neves Siviero² \& Ricardo Coutinho ${ }^{3}$ \\ 1 Universidade do Estado do Rio de Janeiro, Departamento de Ciências. R. Francisco Portela 794, Paraíso, São Gonçalo, \\ RJ, Brazil, 24435-000; lskinner@uerj.br \\ 2 Universidade Federal Fluminense, Programa de Pós Graduação em Biologia Marinha; fnsiviero@yahoo.com.br \\ 3 Instituto de Estudos do Mar Almirante Paulo Moreira, Arraial do Cabo, RJ, Brazil; rcoutinhosa@yahoo.com
}

Received 16-X-2005. C Corrected 05-V-2006. Accepted 16-III-2007.

\begin{abstract}
Growth of the intertidal barnacle Tetraclita stalactifera was compared in two sites under upwelling and tropical influence at Cabo Frio region, Brazil. The hypothesis was that growth is higher at sites with an enhanced productivity. Five quadrates of $10 \times 10 \mathrm{~cm}$ were cleared in an intertidal zone of each site to follow growth from recruitment and onwards. Base diameters were measured for 18 individuals at the tropical site (Ponta da Fortaleza) and 22 at the upwelling site (Ponta da Cabeça) using digitalized photos and ImageTool software. Mean growth rates were $0.07 \mathrm{~mm} /$ day at the tropical site and $0.06 \mathrm{~mm} /$ day at the site under upwelling influence. No effect of location, upwelling season or settlement time was found on barnacle growth rates. Other factors or synergic interactions such as temperature and food availability could influence $T$. stalactifera growth. Rev. Biol. Trop. 55 (Suppl. 1): 71-78. Epub 2007 June, 29.
\end{abstract}

Key words: Cirripedia, bottom-up effect, development, tropical region, temperature.

Coastal upwelling increases food availability and decreases water temperature. These are the two most important characteristics that link oceanographic conditions to organism behavior and physiology. Coastal upwelling can cause effects like an increment on diversity, abundance, and changes on physiological condition in filter-feeding organisms, including growth and survivorship (Pitts 1999, Menge 2000, Menge et al. 2002, 2003, Rutllant and Montecino 2002, Witman and Smith 2003, Soares-Gomes and Fernandes 2005). These environments also induce physiological responses of individuals to temperature variation and food availability (Menge et al. 2002, Brockington and Clarke 2005), and direct influences on reproduction or recruitment (Leslie et al. 2005).
Growth and development of larval stages of many marine invertebrates are affected by food availability and temperature (Anil et al. 2001, Desai and Anil 2004). Food availability affects also energy content in larvae and early development of adults (Anil et al. 2001, Giménez et al. 2004, Marshal and Keough 2004). Physiological response of individuals to temperature variation or food concentration has received little attention (mainly field observations). Some recent studies evaluate the role of environmental characteristics on physiological responses of species (Menge et al. 2002, Sanford 2002), using growth as a tool, mainly for barnacles and mussels (Sanford and Menge 2001, Phillips 2005).

Growth of many crustaceans depends on physiological conditions and energy content, and can be related to environmental 
characteristics such as food availability, temperature, salinity and air exposure, among others (Hartnoll 2001).

Barnacles are good species for ecological modeling and monitoring programs since they can reflect environmental conditions; many species are widespread, easily identifiable and adequate knowledge of their life cycle is available. Their wide distribution allows comparisons among different regions and times.

Tetraclita stalactifera (Lamarck, 1818) is a typical intertidal barnacle species known from western Atlantic Ocean, Gulf of Mexico and eastern Pacific. They live attached to rocks, piers and many other hard substrata; their water temperature range is between 20 and $26^{\circ} \mathrm{C}$. Two subspecies are described for the Brazilian coast: T. stalactifera stalactifera and T. stalactifera floridana Pilsbry, 1916 (Young 1998), and a third subspecies, T. stalactifera confines, has been reported for the Gulf of California. On Brazilian shores, T. stalactifera distribution forms a fringe below high intertidal barnacle
Chthamalus spp. and above intertidal mussel Perna perna.

The present study, conducted at the Cabo Frio upwelling region, southeastern Brazil, aims to compare growth rates of intertidal barnacle $T$. stalactifera on sites under upwelling and under tropical influence. We tested the hypothesis that $T$. stalactifera growth is higher at the upwelling site (Ponta da Cabeça) due to an increase in food availability indicated by water temperature.

\section{MATERIALS AND METHODS}

At Cabo Frio region, we considered two sites with distinct upwelling influences (Guimaraens and Coutinho 2000), which were at a distance of $5 \mathrm{~km}$ from each other: Ponta

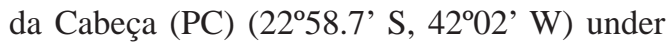
upwelling influence, and Ponta da Fortaleza (PF) (22 $\left.58.1^{\prime} \mathrm{S}, 42^{\circ} 00.8^{\prime} \mathrm{W}\right)$ under tropical influence (Fig. 1). Growth of T. stalactifera was

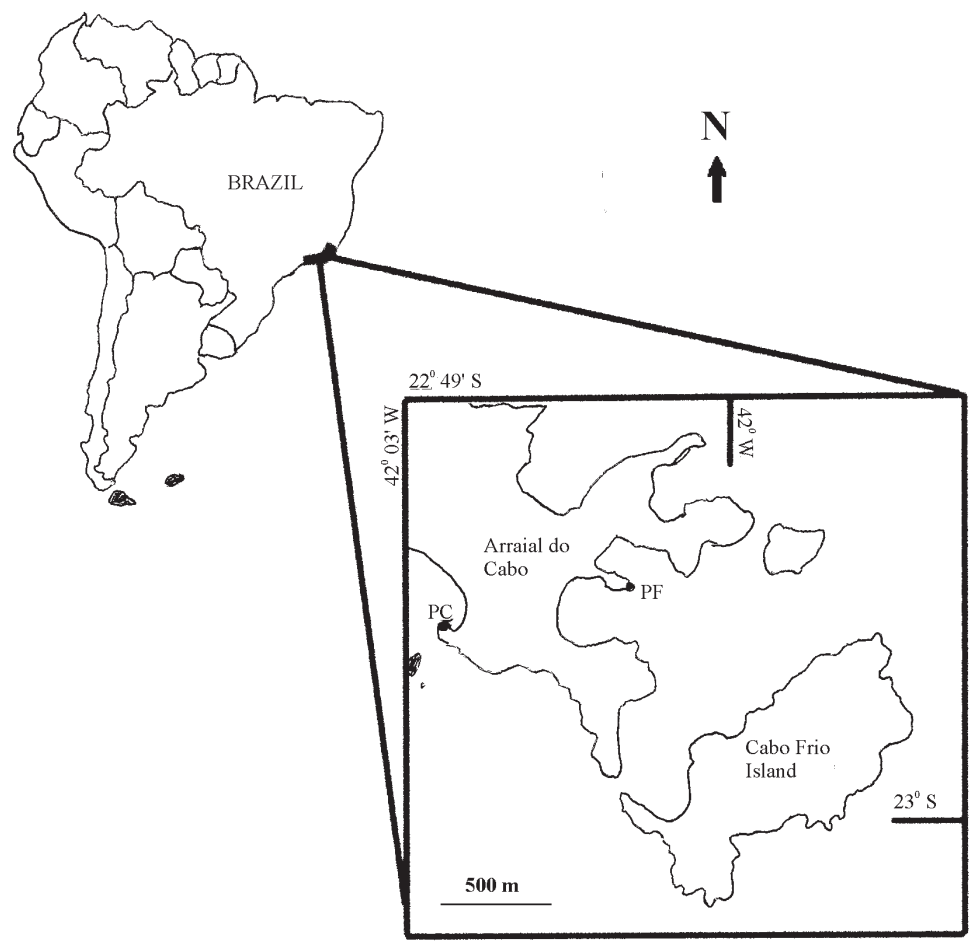

Fig. 1. Study site location and geographic coordinates from southeastern Brazil. Sampling sites: Ponta da Cabeça (PC), upwelling influence; Ponta da Fortaleza (PF), tropical influence. 
monitored at both locations from November 2001 through September 2002.

At each site, five quadrates of $10 \times 10 \mathrm{~cm}$ $\left(100 \mathrm{~cm}^{2}\right)$ were scraped and cleared to evaluate recruitment, substrate occupancy and growth of the intertidal barnacle $T$. stalactifera. Twice a month, sampling was carried out and photos were taken of each quadrate on ISO 200 film using a Canon EOS $300035 \mathrm{~mm}$ with 2X macro filters attached to a 35-80 mm lens. Distance between fixed points on quadrates was used to calibrate the measures. Photos were digitalized, each T. stalactifera individually recorded, and its base diameter was measured using the software ImageTool (UTHSCSA 2006). Base diameter was chosen, because (1) recruitment occurred at low densities at the beginning of the experiment, and (2) due to the small length of opercular aperture at that time. All individuals were measured from its recruitment to its death or until conclusion of the experiment in September 2002. For each individual we established the relation between size and age to estimate growth rate related to time. Surface water temperature was measured to correlate it with growth, allowing us to indicate upwelling and non-upwelling events. It was not possible to measure food availability due to logistical problems, but productivity in the region is related to thermal oscillation with higher productivity at the upwelling site PC (Guimaraens and Coutinho 2000, Carbonel 2003)

We used 18 and 22 individuals from PF and PC, respectively, to evaluate growth of $T$. stalactifera. Age (days) and size ( $\mathrm{mm}$ ) were used to estimate daily growth rate ( $\mathrm{mm} /$ day), and a T-test was used to compare growth rates at both sites and during early (summer $=$ Nov-Apr) and latter (autumn/winter = Apr-Sept) settlement. We also performed a test to check normality and homogeneity of variances (Zar 1998). The relation between age and size was described by performing a linear regression analysis.

\section{RESULTS}

Substrate colonization by $T$. stalactifera barnacles started in January 2002 at Ponta da Fortaleza (tropical influence) and in February 2002 at Ponta da Cabeça (upwelling influence). Surface water temperature showed higher mean values at $\mathrm{PF}\left(23.3^{\circ} \mathrm{C}\right)$ than at $\mathrm{PC}\left(19.9^{\circ} \mathrm{C}\right)$, but water temperature was under seasonal influence. This pattern was observed in summer while from autumn to winter higher temperatures were measured at PC. During autumnwinter, water temperatures were always higher than $20^{\circ} \mathrm{C}$ on both sites (Fig. 2).

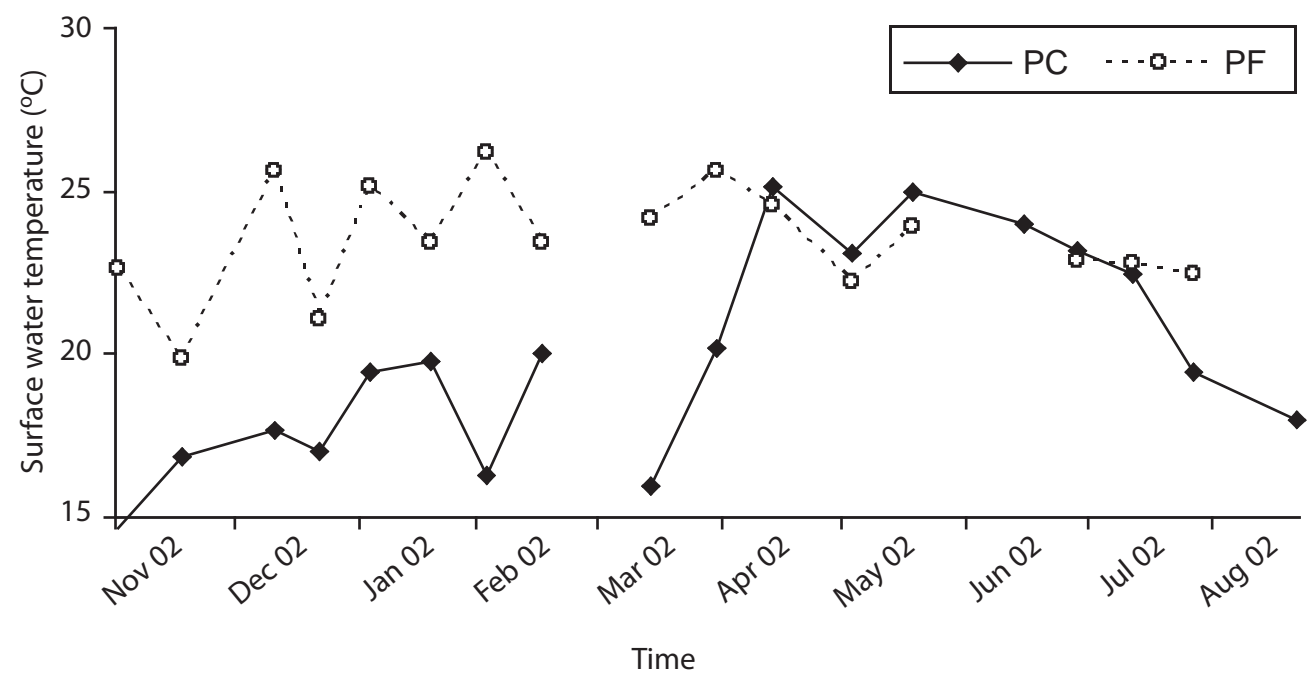

Fig. 2. Surface water temperature $\left({ }^{\circ} \mathrm{C}\right)$ at Ponta da Cabeça (PC, upwelling) and Ponta da Fortaleza (PF, tropical) sites registered twice a month during experimental period. Empty spaces are missing values. 
At the site under tropical influence (PF) we registered the largest individual with a base diameter of $16.67 \mathrm{~mm}$. At the upwelling site (PC), the largest individual had a base diameter of $15.82 \mathrm{~mm}$. Mean daily growth rate was higher at PF $(0.07 \pm 0.05 \mathrm{~mm} /$ day $)$ than at PC $(0.06 \pm 0.03 \mathrm{~mm} /$ day $)$, but this difference was statistically not significant $(\mathrm{T}$-test, $\mathrm{p}>0.05, \mathrm{df}=$ 35 ). The highest individual growth rate of 0.12 $\mathrm{mm}$ /day was registered both at PF and PC for individuals who lived for 57 days.

If barnacle growth rate was size-dependent, a non-linear growth curve could be generated. This assumption was tested for the data from both sites for early (February-March) and late (April-May) settlement. Despite a mean growth rate of $0.07 \mathrm{~mm} / \mathrm{da}$ at $\mathrm{PF}$, growth rate for early and late settlers was $0.08 \pm 0.06$ and $0.06 \pm 0.02$ $\mathrm{mm} /$ day, respectively; however, this difference was statistically not significant (T-test, $\mathrm{p}>0.05$, $\mathrm{df}=39$ ). At PC site, overall mean growth rate was $0.06 \mathrm{~mm} /$ day, that for early and late settlers $0.08 \pm 0.03$ and $0.05 \pm 0.03 \mathrm{~mm} /$ day, respectively. As for PF, there was no statistically significant difference between these cohort growth rates (T-test, $\mathrm{p}>0.05, \mathrm{df}=15$ ). Aside from the slight difference in growth rates between early and late recruiters, statistical analysis showed that growth rate was not related to size or settlement time. This is in agreement with the hypothesis that growth of $T$. stalactifera follows a linear model.

Comparison of growth rates at both sites on different settlement times showed no statistically significant difference (summer; $\mathrm{T}$ test, $\mathrm{p}>0.05$, df $=18$ ) (autumn/winter, T-test; $\mathrm{p}>0.05$, $\mathrm{df}=14$ ), indicating that season had no effect on the growth rates.

The growth curve for $T$. stalactifera at both sites (Fig. 3) did not reveal a limited growth, except for one individual at $\mathrm{PF}$, which reached a plateau. Regression analysis showed a positive and significant relationship between size and age (Table 1), being higher at PF than at PC. Dispersion of points on the growth curves was more pronounced at the PC site, a location with more variable oceanographic conditions.
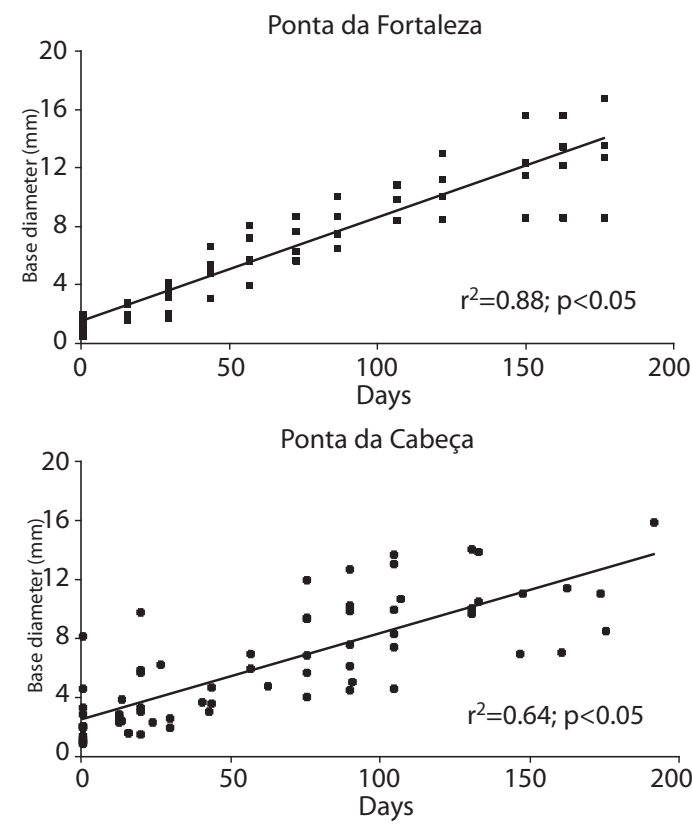

Fig. 3. Base diameter (mm) by age (days) and Pearson regression for intertidal barnacle Tetraclita stalactifera at Ponta da Fortaleza (square symbols= tropical influence) and Ponta da Cabeça (black points= upwelling influence). Continuous line is the adjusted linear regression.

TABLE 1

Results from linear regressions between base diameter ( $\mathrm{mm}$ ) and age (days) for barnacle Tetraclita stalactifera

$\mathrm{X}$ Intercept Coefficient r2 $\mathrm{F} \quad \mathrm{p} \quad \mathrm{df}$

$\begin{array}{lllll}\text { Ponta da } & 2.44 & 0.06 & 0.64 & 118.5<0.05 * 69 \\ \text { Cabeça } & & \end{array}$

$\begin{array}{lllll}\text { Ponta da } & 1.36 & 0.07 & 0.88 & 446.4<0.05 * 64\end{array}$

* Significant difference

\section{DISCUSSION}

We studied growth rates of $T$. stalactifera at sites under different oceanographic conditions. Besides the numeric differences in mean growth rate, no statistically significant difference was noted between the site under tropical influence and the study location under upwelling influence. This result did not support our predictions, because we expected higher growth rates at the upwelling site due to a 
higher availability of food (Valentin et al. 1987, Carbonel and Valentin 1999). No significant differences were found when we compared growth rates within the same site or for the same season but at different sites. Again, these findings were in opposite to those reported by other authors for Balanus glandula (Sanford and Menge 2001) and Semibalanus balanoides (Bertness et al. 1991), where higher growth rates were recorded at sites with higher upwelling influence and wave exposure or higher availability of food.

Our results agree partially with data published by Phillips (2005) who found higher growth rates for $B$. glandula at sites with decreasing upwelling. Phillips (2005) suggested that other factors (e.g., little variability in food availability among sites, off-shore transport of phytoplankton or water temperature, feeding behavior related to cirral activity) could have some influence on these results. These observations are quite similar to our findings, despite the fact that there was no difference concerning growth rate.

Mean growth rate of $T$. stalactifera at the Cabo Frio region during the first year was not limited by size or age and was similar to values reported for other intertidal barnacle species like T. squamosa rubescens (up to $0.03 \mathrm{~mm} /$ day; Villalobos 1979) and S. balanoides (up to $0.12 \mathrm{~mm} /$ day; Sanford and Menge 2001; up to 0.08 mm/day; Phillips 2005). Villalobos (1979) found a continuous decrease in growth rate starting with the first year which is typical for many crustaceans (Hartnoll 2001).

A higher dispersion of size-age data at upwelling sites compared to tropical sites may be related to environmental variability. At tropical sites, temperature remains more stable and larger changes occur seasonally. At upwelling sites, temperature could change in a few hours, and the effects over Tetracilta individuals are different. Despite the absence of statistical difference, this dispersion could be related to these differences in growth rate during upwelling and non-upwelling events (Sanford and Menge 2001, Phillips 2005) and may produce larger differences in long time series. Both behavior and activity of suspension feeding depend on temperature. At $25^{\circ} \mathrm{C}$, cirral activity is high with 90 movements per minute, whereas at 15 ${ }^{\circ} \mathrm{C}$ cirral movement decreases to 30 per minute (Skinner, unpubl. data). Such a change in cirral activity and its effect on physiology and feeding has been reported previously (Southward 1955, 1957, Crisp and Bourget 1985). This reduction affects food intake and physiological condition of the animals (Brockington and Clarke 2005) and could affect growth as well.

In his review on crustacean growth, Hartnoll (2001) described how increasing temperature caused a decrease in intermolt duration and also affected metabolic processes leading to reserve accumulation. Food availability is also important, but for many species higher temperatures may have more positive influence on growth than high availability of food in cold waters. This could explain the differences between our sites, since the low food availability at PF would be compensated by a higher metabolic rate and activity of suspension feeding. In addition, the reproductive pattern could be related to food availability and temperature, and gonad development might be adjusted to this (Ventura et al. 1997).

In contrast to our predictions, early and late settlement at our upwelling site did not produce differences in growth rates, despite the fact that the autumn/winter settlers presented lower growth rates than earlier settlers. Further studies relating food availability, detailed measures of upwelling and non-upwelling events, rate of filtration at different temperatures, and growth marks on barnacles shell could help to determine the role of food availability and temperature on growth of intertidal barnacles.

\section{ACKNOWLEDGMENTS}

We thank CAPES for a Ph.D. scholarship to LFS and FNS, and CNPq for financial support to RC. Thanks also to PPGB-UERJ and IEAPM for facilities, and to anonymous referees and Ingo Wehrtmann for suggestions. 


\section{RESUMEN}

El crecimiento del cirripedio intermareal Tetraclita stalactifera fue comparado en dos sitios influenciados por condiciones de resurgencia y tropicales en la región del Cabo Frio, Brasil. La hipótesis fue que el crecimiento es más grande en el sitio con más elevada producción. En esta región, cinco cuadrantes de 10 x $10 \mathrm{~cm}$ fueron raspados en el intermareal de las costas rocosas, en cada una de estas localidades, para estudiar el crecimiento de T. stalactifera desde el reclutamiento hasta finalizar el experimento o la muerte del individuo. El diámetro de la base de T. stalactifera fue medido para 18 individuos en el sitio tropical (Ponta da Fortaleza) y 22 en el sitio de resurgencia (Ponta da Cabeza) por medio de fotografías digitalizadas y el software ImageTool. Los resultados observados mostraron una mayor tasa de crecimiento en el área bajo la influencia tropical $(0.07 \mathrm{~mm} / \mathrm{día})$ que en el área bajo influencia de resurgencia $(0.06 \mathrm{~mm} /$ día). La localización del sitio, periodo de resurgencia o periodo del asentamiento no afectaron las tasas de crecimiento. Otros efectos o interacciones sinérgicas como la temperatura y la disponibilidad de alimento pueden afectar el crecimiento de esta especie en la región.

Palabras clave: Cirripedia, efecto bottom-up, desarrollo, región tropical, temperatura

\section{REFERENCES}

Anil, A.C., D.V Desai \& L. Khandeparker. 2001. Larval development and metamorphosis in Balanus amphitrite Darwin (Cirripedia: Thoracica): significance of food concentration, temperature and nucleic acids. J. Exp. Mar. Biol. Ecol. 263: 125-141.

Bertness, M.D., S. Gaines, D. Bermúdez \& E. Sanford. 1991. Extreme spatial variation in the growth and reproductive output of the acorn barnacle Semibalanus balanoides. Mar. Ecol. Progr. Ser. 75: 91-100.

Brockington, S. \& A. Clarke. 2005. The relative influence of temperature and food on the metabolism of a marine invertebrate. J. Exp. Mar. Biol. Ecol. 258: 87-99.

Carbonel, C.A.A.H. 2003. Modelling of upwelling-downwelling cycles caused by variable wind in a very sensitive coastal system. Cont. Shelf. Res. 23: 15591578.

Carbonel, C.A.A.H. \& J.L. Valentin. 1999. Numerical modelling of phytoplankton bloom in the upwelling ecosystem of Cabo Frio (Brazil). Ecol. Model. 116: 135-148.
Crisp, D.J. \& E. Bourget. 1985. Growth in barnacles. Adv. Mar. Biol. 22: 199-244.

Desai, D.V. \& A.C. Anil. 2004. The impact of food type, temperature and starvation on larval development of Balanus amphitrite Darwin (Cirripedia: Thoracica). J. Exp. Mar. Biol. Ecol. 306: 113-137.

Giménez, L., K. Anger \& G. Torres. 2004. Linking life history traits in successive phases of a complex life cycle: effects of larval biomass on early juvenile development in an estuarine crab, Chasmagnathus granulata. Oikos 104: 570-580.

Guimaraens, M.A. \& R. Coutinho. 2000. Temporal and spatial variation of Ulva spp. and water properties in the Cabo Frio upwelling region of Brazil. Aquat. Bot. 66: 101-114.

Hartnoll, R.G. 2001. Growth in Crustacea - twenty years on. Hydrobiologia 449: 111-122.

Leslie, H.M., E.N. Breck, F. Chan, J. Lubchenco \& B.A. Menge. 2005. Barnacle reproductive hotspots linked to nearshore ocean conditions. Proc. Nac. Acad. Sci. 102: 10534-10539.

Marshall, D.J. \& M.J. Keough. 2004. Variable effects of larval size on post-metamorphic performance in the field. Mar. Ecol. Progr. Ser. 279: 73-80.

Menge, B.A., 2000. Top-down and bottom-up community regulation in marine rocky intertidal habitats. J. Exp. Mar. Biol. Ecol 250: 257-289.

Menge, B.A., A.M. Olson \& E.P. Dahlhoff. 2002. Environmental stress, bottom-up effects, and community dynamics: integrating molecular-physiological and ecological approaches. Integ. Comp. Biol. 42: 892-908.

Menge, B.A., J. Lubchenco, M.E.S. Bracken, F. Chan, M.M. Foley, T.L. Freidenburg, S.D. Gaines, G. Hudson, C. Krenz, H. Leslie, D.N.L. Menge, R. Russell \& M.S. Webster. 2003. Coastal oceanography sets the pace of rocky intertidal community dynamics. Proc. Nac. Acad. Sci. 100: 12229 -12234 .

Phillips, N.E. 2005. Growth of filter-feeding benthic invertebrates from a region with variable upwelling intensity. Mar. Ecol. Progr. Ser. 295: 79-89.

Pitts, P.A. 1999. Effects of summer upwelling on the abundance and vertical distribution of fish and crustacean larvae off central Florida's Atlantic coast. J. Exp. Mar. Biol. Ecol. 235: 135-146. 
Rutllant, J. \& V. Montecino. 2002. Multiscale upwelling forcing cycles and biological response off north-central Chile. Rev. Chil. Hist. Nat. 75: 217-231.

Sanford, E. 2002. Water temperature, predation, and the neglected role of physiological rate effects in rocky intertidal communities. Integ. Comp. Biol. 42: 881891.

Sanford, E. \& B.A. Menge. 2001. Spatial and temporal variation in barnacle growth in a coastal upwelling system. Mar. Ecol. Progr. Ser. 209: 143-157.

Soares-Gomes, A. \& F.C. Fernandes. 2005. Spatial distribution of bivalve mollusc assemblages in the upwelling ecosystem of the continental shelf of Cabo Frio, Rio de Janeiro, Brazil. Rev. Bras. Zool. 22: 73-80.

Southward, A.J. 1955. On the behavior of barnacles. I. The relation of cirral and other activities to temperature. J. Mar. Biol. Assoc. UK 34: 403-422.

Southward, A.J. 1957. On the behavior of barnacles. III Further observations on the influence of temperature and age on cirral activity. J. Mar. Biol. Assoc. UK 36:323-334.

Valentin, J.L., D.L.André \& S.A. Jacob. 1987. Hydrobiology in the Cabo Frio (Brazil) upwelling: two-dimensional structure and variability during a wind cycle. Cont. Shelf. Res. 7: 77-88.
Ventura, C.R.R, A.P.C. Falcão, J.S. Santos \& C.S. Fiori. 1997. Reproductive cycle and feeding periodicity in the starfish Astropecten brasiliensis in the Cabo Frio upwelling ecosystem (Brazil). Invest. Reprod. Dev. 31: 135-141.

Villalobos, C.R. 1979. Variations in population structure in the genus Tetraclita (Crustacea: Cirripedia) between temperate and tropical populations. I. Fecundity, recruitment, mortality and growth in T. rubescens. Rev. Biol. Trop. 27: 279-291.

Witman, J.D. \& F. Smith. 2003. Rapid community change at a tropical upwelling site in the Galapagos Marine Reserve. Biodiv. Conserv. 12: 25-45.

Young, P.S. 1998. Maxillopoda. Thecostraca, p. 263-285. In P.S. Young (ed.). Catalogue of Crustacea of Brazil (Série Livros N6), Museu Nacional, Rio de Janeiro, Brazil.

Zar, J.H. 1998. Biostatistical Analysis. Prentice Hall, Englewood Cliffs, New Jersey, USA. 929 p.

\section{INTERNET REFERENCES}

UTHSCSA. 2006. ImageTool Application. University of Texas Health Science Center at San Antonio Dental School (Downloaded: May 25, 2006, http://ddsdx. uthscsa.edu/dig/download.html). 
